\title{
腹水腫瘍 の細胞化学的研究
}

\author{
第 III 編 \\ 脱水素䣼素系に対する制癌物質皮下投与の影響*
}

椆山大学医学部第 1 外科教室（指導：阵内傅之助教授）

河島隆男

[昭和 38 年 2 月 13 日受稿]

\section{緒言}

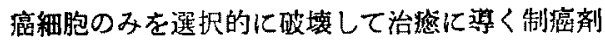
の研究は, 現在では癌化学療法の大勢である。しか し Berge11)によれば，癌細胞を正常細胞に变える ことはできないが，癌細胞中の䣼浆不均衙交訂正す るような物質の連続投与によつて癌細胞の異常な活 動性を制繁していく試みがある。

本実験では問題点を DPN に限局させ，これに関 連する制癌物兵の酸化酵䒺に対する影響を検討した。 悪性腫場組織中の DPN 量は正常組織に比較して低 いという事実2-11) 加，諸家により緗胞分裂之 DPN 量との関係が追求されてきた。 そして藤井12) 松山13 ${ }^{13}$ nicotinamide 及び DPN の投与による稩 胞内 DPN 量の增加があれば，正常及び腫瘍組織の 増殖が抑制されると主張している。

しかし一方 Roitt, Holzer ら14)によれば, ある 種の制獖剂の投与により DPN 量は堿少するが， これはての制噪剂の抗腫第性を示すとしている。

すなわち nicotinamide 及び DPN などで腫㻛細 胞内の DPN 量をより增加させると分裂が抑制され るが、また一方 endoxan (N, N-bis ( $\beta$-chloraethyl). $\mathrm{N}$, O-propytenephosphoric acid ester diamide) 及 び mitomycin C などの制癌凨により分裂が抑制さ れると DPN 量はより減少する。

さらに菭楅(5)に上ればテトラヒメナにおいて DPN 量はこの生活環に関連して增減しており， nicotinamide がこの温度処理後から分裂までの DPN 量の增加を防ぐと同時に，分裂を抑制するこ とを報告した。

本編においては上述の上うに DPNを增減させ る endoxan, nicotinamide, DPN 及びこれらの対
照として DPN に関係かないとされる colchicine を投与しておこる腹水癌細胞の diphosphopyridine nucleotide disphorase (DPNHD), triphopyridine nucleotide diaphorase (TPNHD), succinic dehydrognase (SD), 及び $\boldsymbol{a}$-glycerophosphate dehyderogenase ( $\alpha$-GD) の変化を Ehrlich 腹水癌細胞を用いて 細 胞化学的に検刢した、なお第編16)においては制 癌物空を腹腔内投与としたためにての直接作用をさ けることができなかつたので，本編ては 4 種類の薬 猟ともすへて皮下投与とした。

\section{実験材料及び実験方法}

塩野義研究所より剚渡された Ehrlich 腹水鹰を $25 \mathrm{~g}$ 前後の dds アゥスに栘植し，7日後より制癌 物顀を各々 5 匹ずつに投年した。

endoxan は $0.5 \mathrm{mg} /$ 匹を 3 日間連綕投与して 24 時問後, nicotinamide は Kaplan ら17)に準じて 15

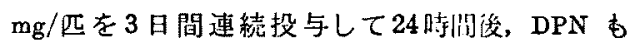
Kaplan ら17)に準じて $40 \mathrm{mg}$ /匹を投与して 4 時間 後, colchicine は武田18) 汇準じて 4\%/匹を投与し て12時間後の腹水留を採取した，乙れを染抹法及 び浮遊法16)19）を用いて実験した。この钼察には 普通影微澺，位相差颢微鏡及びFormazan-Haematoxylin 重染色19）を用いた。また細胞化学反応

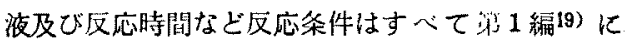
準じた。

染色の対照には移植後同日数を経た腹水括を用い， 各制癌物宙投与による細胞変化の観察には位相差影 微鏡及び May-Giemsa 染色を用いた。なお DPN 投与群においては細胞化学反応の対照として反応液 に DPN $3 \mathrm{mg} / \mathrm{ml}$ 加えたものを用いて実験したか， DPN を加えない場合之同一の染色絬果をえた。

* (本論文の要旨は第21回日本嵒学会において発表した.) 


\section{実 鋻成維}

Endoxan 投与群：May-Giemsa 染色標本では細 胞犋む核も同様に腫脤し，核破壊像が散見され，䚀 胞分裂は著減し，分裂はほとんど異常分裂であつた。

整抹法では 4 酵菜とす対照に等しい染色性を示し t.

浮遊法では DPNHDにおいて濃染する細胞が対 照に比して增加しており，約30\%を占めた．

他の淡染または陰性の紐胞の染色性にはほとんど 変化を認めなかつた. TPNHDの染色性は対照に比 してほとんど变化がなかつた，SD 及び $\boldsymbol{\alpha - G D の ~}$ 染色性の対照に比して一般に軽度の立進を示してい た。分裂細胞の場合 4 醭菜ともはとんど陰性であつ た (Fig. 1 4).

Nicotinamide 投与群：休止期及び分裂期を通 じて形態学的には著变を認めないが，分裂紐胞は1/2 以下に減少した.

筀抹法では4 酵菜とす染色性に変化はなかつた。

浮遊法では DPNHD 及び TPNHD の染色性に おいて，著しく漂染する細胞がごく怪度に增加して 全体の約15\%をを占めたが，ての他に著变を認めなか つた，SD 及び $\boldsymbol{a}$-GD の染色性も変化はなかつた (Fig. 5 8).

DPN 投与群：すへてての細胞に形態学的変化を認 めることはできなかつたが，分裂細胞は nicotinamide の場合以上に減少した。

染抹法では 4 醅菜と染色性の变化を認めること はできなかつた。

浮遊法では DPNHD の著しく溜染した細胞が全 体の20\%に増加していたが，他の谈染した細胞など は対照と同様の染色性を示した。 TPNHD の染色 性は一般に染色性増加の傾向にあつたが，はとんど

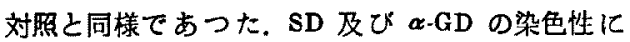
あ変化は認められなかつた（Fig. 9～12).

Colchicine 投与群：May-Giemsa 染色標本ては 休止期の細胞に変化がなく，次々に分裂するか，分 裂前期から中期で阻止された分裂中絶細胞及び矮小 細胞が出現していた。

染抹法では DPNHD 及び TPNHD の染色性に 変化はなかつたが, SD 及び a-GD の染色性は軽 度に低下していた（Fig. 13〜16）。

浮遊法では DPNHD の染色性は詨照と変りなく， TPNHDでは全般的にみる亡変化はないようであ つたか，著しく浀染した細胞が僅かに減少していた。
SD は中染した細胞が增加して明かに染色性の元進 がみられた， $\alpha$-GDは一般に染色性に変化がなかつ た。分裂中絶細胞及び矮小細胞は 4 䣼菜之も陰性で あつた（Fig. 17〜20).

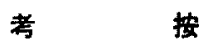

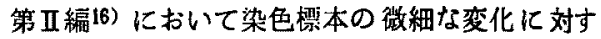
る意味づりが危険であることを述へたが，本編にお いても同様にどく明暸な diformazan 沈着の変化の みを検㶦した。

Endoxan 投与群 : endoxan は nitrogen mustard

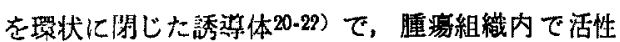
型に变化する所の transport form となつており(4), アルキル化剂中最も有效上されている23). 勿諭 Ehrlich 腹水癌にも，杉浦24）によれば著効がある こいう。 そして対照で明らかなように腫演細胞は細 胞全体が腫脤するが，Mölbert 25)，Büchner 26)， Themann27) らによればミトコンドリアもそれに平 行して腫脤しているという，との形態学的变化をき たした細胞はこの DNA 代射を阻害され，RNA 合 成が促進されているという28)。 さらに2次的におと る見象上考えられるが，細胞内 DPN 量が著しく 減少するという28292。 したがつて DPN の娍少に 対する DPNHD の変化を娭討するととは，興味深 いことである.

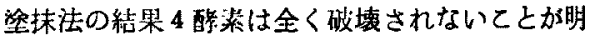
らかとなつた。

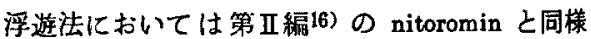
に細胞膜の透過忙が亢進してるいことは疑いないか ら，染色性だけで活性を論ずるわけにはいかない。 したがつて第 1 編19〉の実験 3 における透過性え進 浮遊法と比較しつつ活性を推察することにする。

endoxan のアルキル化反応により，細胞は腫脤し て分裻細胞は滅少するが, DPNHDの染色性は立 進しており，泳染細胞が30\%をを占めるが，とれは実 際に活性が亢進したのか，分裂阻墨のために DPNHD 高活性の細胞が増加してくるのか，または透過 性穴進のために淎染したすのと考えることができる。 TPNHD の染色性には変化がないが，とれは TPNHD活性に何の变化もないか怪度に低下しているか のどちらかであろう. SD 及び $\alpha$-GDの染色性は 轻度にえ進しているが，これは透過性え進のために よるむのか，実際に活性が穴進しているのか明らか でない，第 1 編19》によれば，SD 及び $a$-GD は分 裂期以外は一定の活性を示すか, endoxan による場 
合も同様で，腫場細胞内のてれら非常に低い活性を 示す代謝系が endoran 亿上つて元進する兆候がほ とんどないととを示している. また細胞内の DPN

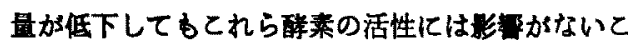
とを示している. 勿論分裂細胞は4 醇素活性とす陰 性である。

以上を㴔括すれば, endoran によつて DPNHD 活性は轻度に元進するのか高活性の細胞が増加する のか，または活性が不変であるが細胞膜の透過性が 亢進しているかのいずれかであり，TPNHD 活性は 変化がないか軽度に低下しているかでりり，SD 及 び $\boldsymbol{a}$-GD 活性は軽度に元倠しているか变化かない かである.

Nicotinamide 投与群: 一般に胎生組織及び腫場 組䋐のような活発な成長組織の Pyridine nucleotide 含量は少ないが2-11)，とれは Blaster9)によれば pyridine nucleotide の破壊の增加よりもむしろそ の合成の減少に上ると推定している，ての低い pyridine nucleotide 含量の隀湯は大出30), Morton31), Sahsarabudhe32) らによ机ば細胞增殖率之関係があり， 低い pyridine nucleotide 量の場合飞 feed back 機 作によつて細胞分裂か誘起される31132）という。を こで細胞内 DPN 量の増加をきたせば缰洦細胞の 增殖が抑制されるという観点から諸家により㯵場に 対して nicotinamide がしばしば投与されてきた。

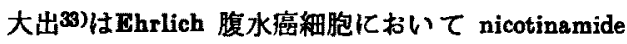
の投与により約 1.7 倍の DPN 增加をみており， Kaplan 51734) は L $\mathrm{L}_{1210}$ 白血病細胞化おいて約 2 倍，

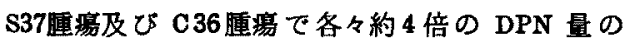
増加をみている．この状態で正常または重場細胞の

增殖は抑制されるという。北村35) らによれば $\mathbf{A H}$ 130腹水癌紐胞で分裂細胞数は $1 / 2$ 以下となり，藤 井12）によれば Ehrlich 腹水癌で40-7096分裂を㧕 制するとしている．また松山らは)は MC 肉瘇の発 生と成長を勃果的に郊げるとしている.

この機作については藤井12) は細胞内 DPN 合成 の促進か，分解低下のどちらかを予想している.す で飞 Mann ら36), Zatman ら 37), Nason ら38), Kaplan ら39)により, nicotinamide による diphosphopyridine nucleotidase の阻害加明らかにされて いるから，分解の抑制がおこることは間遠いない。 しかし nicotinamide が DPN の前駆物犋であるこ とから合成の促進も推察される，との DPN 量増加 に際して DPNHD 及び TPNHD がいかに激くか 興味ある問題である。
塑抹法の結果では 4 醭素の破壊は考えられない. 浮遊法では DPNHD 及び TPNHD の潧染細胞 が15\%程度であり，僅かに增加している㑯向にある がほとんど変化はみられない，乙の事実と分裂緗胞 か隇少している事実と考え合せると，乙の分裂抑制 作用によつて細胞分裂が減少してあ，てれら醉素に はあまり影幚がなく，休止期の終りに達しえた細胞 の DPNHD 及び TPNHD 活性はやはり高くなる ことを示していると同時に，その時期の細胞が増加 しているととが推察される. Mann ら36)によれば SD K nicotinamide を添加してもSD 活性はほと んど変らない. 本実験です SD 及び $\alpha-G D$ 活性に 変化はなかつたが，とれは nicotinamide が直接と れらに作用しないととを意味する以外に，緗胞内 DPN 量が増加してす国嗱細胞内のこれらの低い醉 菜活性が分裂期以外の時期の細胞であつても正常な 䣼素活性に戾らないことを示すあのである. 勿論分 裂期では4醭素活性とす䧔性である.すなわち DPN 添加により腫浧練胞中のクエン酸回路の活性 が変化しないという Dвjani ら40)の結果と一政す る.

以上を秎括すると nicotinamde は DPNHD 及び TPNHD 高活性の細胞を㮖に増加させるが，これは 活性自身が光進するためか休止期末期の細胞が増加 するためか明らかでない，SD 及び $\alpha$-GD 活性は 変化しない。

DPN 投与群：nicotinamide 投与群で述へたよう に細胞内の DPN 量と細胞分裂との問には密接な関 係か子存在する.Kaplan ら17)34) は DPN を投与し て2 時間後に正常マウスの肝組織の DPN 最加最高 值となるとし，さらに L 1210 白血病マウスに投与し て12時間後の DPN 量を報告しているが, 腫演細 胞の DPN 量の增加は1.12倍である. しかし北村 ら35)によ机 $\mathrm{AH} 130$ 腹水肝癌で DPN 投与に よる細胞分裂が対照に比して $1 / 3$ 以下に減少してお り，また松山らは）は MC 肉腫の発生と成長の抑 制に効果があるとしている。このように細胞内の DPN 量がこくく軽度に増加しても細胞分裂を抑制し ているので，DPN の投与による他の酵素に及ぼす 影帮を検する必要がある。

染林法の結果では4 醉䒺の破填は考えられない。

浮遊法においては，DPNHD では高活性の細胞 加約20\%と僅加に增加している以外には対照と同様 の活性を示している。これは DPNHD 自身の活性 の変化ではなくて, 分裂減少のために休止期の終り 
の高活性稩胞が僅かに增加したと推察することがで きるが，一方 TPNHD 活性には变化がないからゃ はり DPNHD 活性が僅玑穴進していると考える のが罗当であろう. SD 及び $\boldsymbol{\alpha}$-GD 活性す变化は ないかこれも Dajani ら40)の生化学的結果と同 様である，勿論分裂細胞の 4 醉菜活性は陰性である。 以上を総括すれば DPNHD 活性は僅かに圥進す るが、TPNHD，SD 及び 掣もない。

Colehicine 投与群: colchicine は ATPase 阳害 剂であるが41，第糄16) のように大量を使用す れば DPNHD 及びTPNHD 活性が著しく阻㕩さ れる.したがつて本編ではでく少星の投与に止め た.

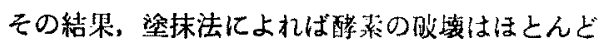
なく，ただ SD 及び $\boldsymbol{\alpha}$-GD に怪度の破壊が考えら れる。

浮遊法でも SD を除く 3 醉䕀比著变は認められな かつた，ただ SD活性は克進していた，分裂中絶細

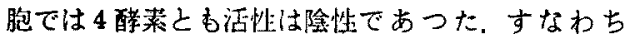
colchicine は少量では SD 及じ $\alpha \cdot G D$ を軽度に破 填し，SD 活性を亢進させる。

結論

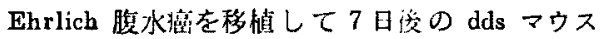
K endoxan, nicotinamide, DPN 及び colchicine の 4 種の制隐物犋を皮下に投与し， ての腹水癌細胞 $\odot$ diphosphopyridine nucleotide diaphorase (DPN-

文

1) Bergel, F. : Chemistry of Enzymes in Cancer, Blackwell Scientic Publications, Oxford (1961).

2) Euler, H., F. Schlenk, H. Heiwinkel \& B. Hörberg : Z. Physiol. Chen. 256, 208 (1938).

3) Kensler, C. J., K. Sugiura \& C.P. Rhoads : Science 91, 76 (1940).

4) Bernheim, F. \& A.V. Felsovanyi: Science 91, 76 (1940).

5) Carruthers, C. \& V. Suntzeff : Arch. Biochem. Biophys. 45, 10 (1953).

6) Strength, D. L. \& M. A. Seibert: Proc. Am. Assoc. Cancer Research 1, 47 (1954).

7) Jedeikin, L.A. \& S. Weinhouse: J. Biol.
HD), triphcsphopyridine nucleotide diaphorase (TPNHD), succinic dehydrogenase (SD) 及び a-glycerophosphate dehydrogenase ( $\boldsymbol{\alpha}$-GD) の変勤を染抹 法及び浮遊法を用いて細胞化学的に䚁察した結果， つぎの結諭をえた。

1）一般に細胞分裂の阻赛を主とした変化が形態 学的に観察されたが，これら酸化酵婆の破裳減少は なく，その活性の変化も僅少であつた。

2) endoxan の場合，細胞膜透過性の変化を老慮 して検封すると，DPNHD，SD 及び $\alpha$-GD 活性は 棸度にえ焦しているかまたは不変であり，TPNHD 活性は変化がないかまたは軽度に低下しているかで おつた。

3) nicotinamide では, DPNHD 及び TPNHD の高活性細胞加佔加に增加し，SD 及び $\alpha$-GD 活性 比は変化がなかつた。

4) DPN では DPNHD の高活性細胞が軽度に増 加し，TPNHD, SD 及び $\alpha$-GD 活性に変化はなか つた.

5) colchicine では4\%/匹では DPNHD, TPNHD 及び $\propto-G D$ 活性に变化なく, SD 活性のみ怪度に元 進した。

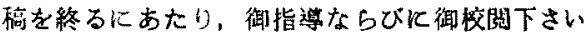
ました恩師陣内教授，田中助教授及び緒方護師を始 め漣内外科癌研究玨の諸兄，及び材料を提供して下 さいました塩野姜研究所峰下博士らK对し深甚の謝 曾をささげすす。

\section{献}

Chem. 213, 271 (1955).

8) Jedeikin, L. A. \& S. Weinhouse: Proc. Am. Assoc. Cancer Research 2, 26 (1955).

9) Branster, M. V. \& R. K. Morton: Biochem. J. 63, 640 (1956).

10) Grock, G. E. \& P. Mclean: Biochem. J. 65 , 413 (1957).

11) Dietrich, L. S., L. A. Kaplan, I. M. Friedland \& D.S. Martin: Cancer Research 18, 1272 (1958).

12）藤非隆: 文部省研究報告集録（涉）(1960).

13) Matsuyama, M. \& T. Nagayo: Cann 51, 265 (1960).

14) wilmanns, H. : 臨床 6, 203 (1960). 
15）高椅秦常：文部省研究報告集録（浩）10(1960).

16）河島隆男：岡山医学会雑誌へ投稿中.

17) Kaplan, N. D., A. Goldin, S. R. Humphreys, M. M. Ciotti \& E. E. Stolzenbach: J. Biol. Chem. 219, 287 (1956).

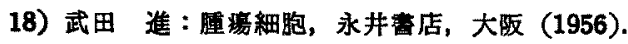

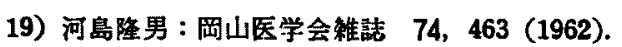

20) Arnold, H., F. Bourseaux \& N. Brock: Die Naturwissenschaften 45, 64 (1958).

21) Lane, M. \& M. G. Kelly: Proc. Am. Assoc. Cancer Research 3, 35 (1959).

22) Venditti, J. M., S. R. Humphrey \& A. Goldin: Cancer Research 19, 986 (1959).

23) Stock, C. C. \& K. Sugiura: Ann. New York Acad. Sci, 68, 853 (1958).

24) 杉浦兼松: 癌の臨床 6,190 (1960).

25) Mölbert, E. : Beitr. Path. Anat. 118, 203 (1957).

26) Büchner, F. : Handbuch der Allgemeinen Pathologie IV/2, S. 569 (1957).

27) Themann, H. \& G. Schmidt: 9. Tagg. der Dtch. Ges. für Elektronenmik roskopie, Freiburg (1959).

28) Grundmann, E., H. Krn̈ger \& H. Holzer :
Klinische Wochenschrift 38, 546 (1960)

29) Holzer, H. \& H. Kröger: Klin. Wschr. 36, 677 (1958).

30) Oide, H.: Gann 49, 49 (1958).

31) Morton, R. K. : Nature, 181, 540 (1958).

32) Sabsarabudhe, M. B.: Nature, 182, 163 (1958).

33) Oide, H.: Gann 50, 177 (1959).

34) Kaplan, N. O., A. Goldin, S. R. Humphreys, M. M. Ciotti \& J. M. Venditti : Science 120, 437 (1954).

35）北村直次，小柴，姝尾：日本癌学会記事，第21 回総会 141 (1962).

36) Mann, P. J. G. \& J. H. Quastel: Biochem. J. 35, 502 (1941).

37) Zatman, L. J., N. O. Kaplan \& S.P. Colowick: J. Biol. Chem. : 200, 197 (1953).

38) Nason, A., N. O. Kaplan \& S. P. Colowick: J. Biol. Chem. 188, 397 (1951).

39) Kaplan, N. O., S. P. Colowick \& A. Nason : J. Biol. Chem. 191, 473 (1951).

40) Dajani, R. M., T. Daniklshi, W. Gamble \& J. M. Orten: Biochem. J. 81, 494 (1961).

41) Lang, K., et al: Experimentia 7, 379 (1951),

\section{Explanation of Figures}

1) Endoxan admimistration group

Fig. 1-4: Suspension method used nitro-BT, $\times 1000$

Fig. $1:$ DPN diaphorase, Fig. $2:$ TPN diaphorase, Fig. $3:$ SD, Fig. $4: \alpha-$ GD

Upper half shows microscopic figures without counter staining.

Lower half shows diformazan-haematoxylin counter staining figures.

Stainabilities of the DPN diaphorase, SD and $\alpha$-GD are slightly intenser than that of control tumor cells (Fig. 1, 3 and 4).

2) Nicotinsmide administration group

Fig. 5-8 : Suspension method used nitro-BT, $\times 1000$

Fig. 5: DPN diaphorase, Fig. $6:$ TPN diaphorase, Fig. $7:$ SD, Fig. 8: $\alpha$-GD

Upper half shows microscopic figures without counter staining.

Lower half shows diformazan-haematoxylin counter staining figures.

In Fig. 5 and 6, the number of cells reacted intensely is increased in lesser degree.

3) DPN administration group

Fig. 9-12: Suspension method used nitro-BT, $\times 1000$

Fig. $9:$ DPN diaphorase, Fig. $10:$ TPN diaphorase, Fig. $11:$ SD, Fig. $12: a \cdot G D$

Upper half shows microscopic figures without counter staining.

Lower half shows diformazan-haematoxylin counter staing figures. 
In Fig. 9, the cells reacted intensely are slightly increased in number.

Note the negative or little reaction in the mitotic phase (Fig. 1-12).

4) Colchicine administration group

Fig. 13-16: Smear method used nitro-BT, $\times 1000$

Fig. 17-20: Suspension method used nitro- BT, $\times 1000$

Upper half shows microscopic figures without counter staining.

Lower half shows diformazan-haematoxylin counter staining figures.

Fig. 13 and $17:$ DPN diaphorase, Fig. 14 and $18:$ TPN diaphorase, Fig. 15 and $19:$ SD, Fig. 16 and $20: \alpha-G D$

Stainabilities of the SD and $\alpha$-GD in the smear method are slightly weaker than that of control tumor cells (Fig. 15 and 16), while stainability of the SD in the suspension method is slightly intenser than that of control (Fig. 19).

Note the nigetive reaction in the metaphase-arrested cells (Fig. 17-20).

A Cytochemical Study on Ascites Tumor

Part 3. Effect of Endoxan, Nicotinamide, DPN and Colchicine on Four Oxidative Enzymes of Ehrlich Ascites Tumor Cells By

\section{Takao Kawashima}

First Department of Surgery, Okayama University Medical School, Okayama, Japan

The four kinds of anti-tumor agents i.e. endoxan (0.5 mg per mouse, three times), nicotinamide (15 mg per mouse, three times), DPN (40 mg per mouse, one time) and colchicine (4 mg per mouse, one time) were subcutaneously administered to dds-mice which had been transplanted with Ehrlich ascites tumor seven days previously. And the changes, of the activity of the DPN diaphorase, TPN diaphorase, succinic degydrogenase (SD) and $\alpha$ glycerophosphate degydrogenase ( $\alpha$-GD) of the ascites tumor cells were cytochemically examined in the smear method and suspension method.

1) In general, their was no definite morphological change of the cells except for inhibition of mitosis in the above dosages, nor destruction of the enzymes. But a few variations of the enzymatic activity were noted.

2) After the administration of endoxan, stainabilities of the DPN diaphorase, SD and $\boldsymbol{\alpha}$-GD were slightly increased, while that of the TPN diaphorase showed no change.

3) After the administration of nicotinamide, the number of tumor cells with the high activity of the DPN diaphorase and TPN diaphorase was increased about five per-cent. NO change of the activity of the SD and $\alpha$-GD was observed.

4) After the administration of DPN, the number of tumor cells with the high activity of the DPN diaphorase was increased about ten per-cent. But no change of the TPN diaphorase, SD and $\alpha$-GD was observed.

5) After the administration of colchicine, there was no change of the activity of the DPN diaphorase, TPN diaphorase, $\alpha$-GD, while the SD activity was increased in lesser degree. 
河島論文附図
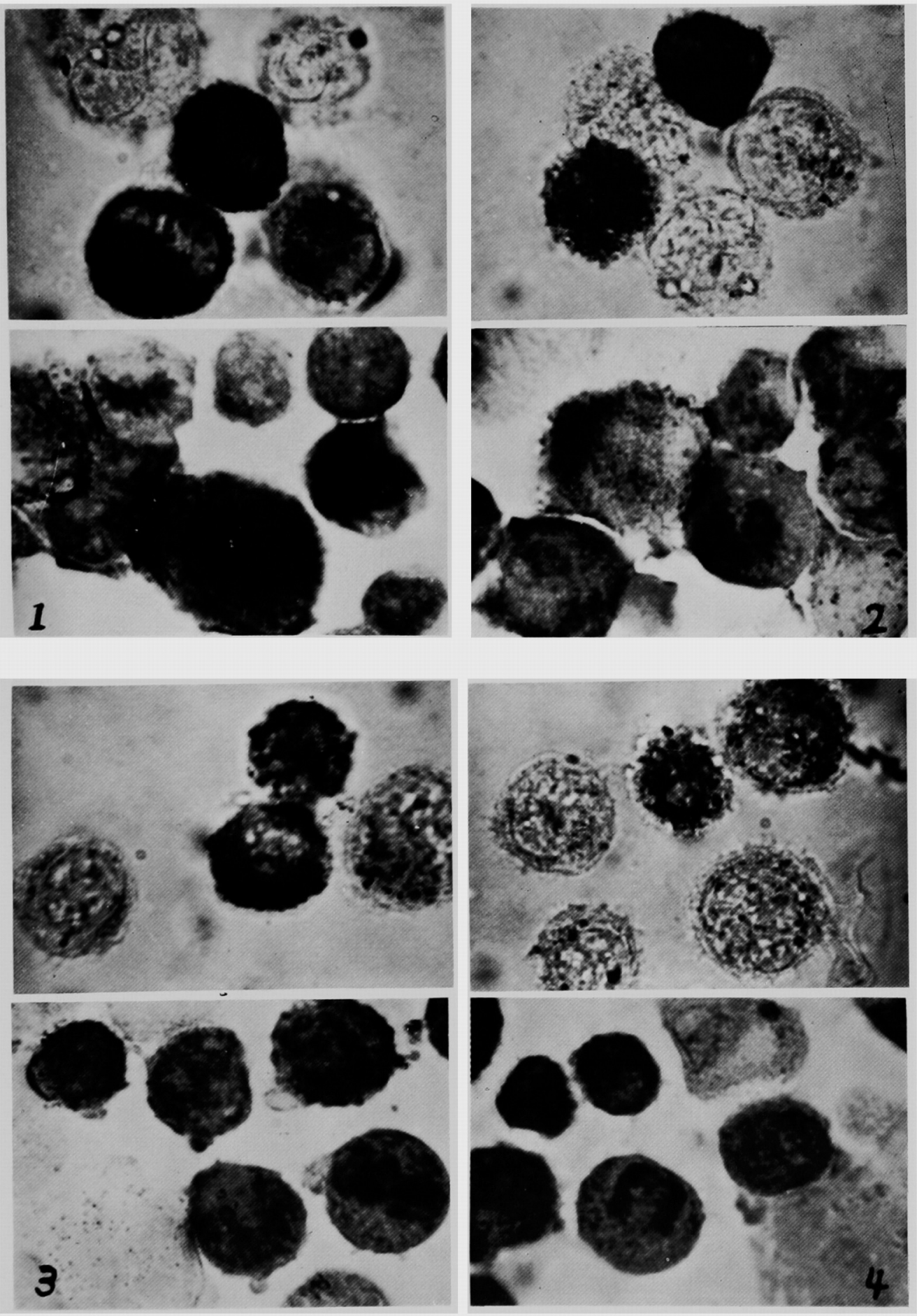


\section{河岛論 文附 図}
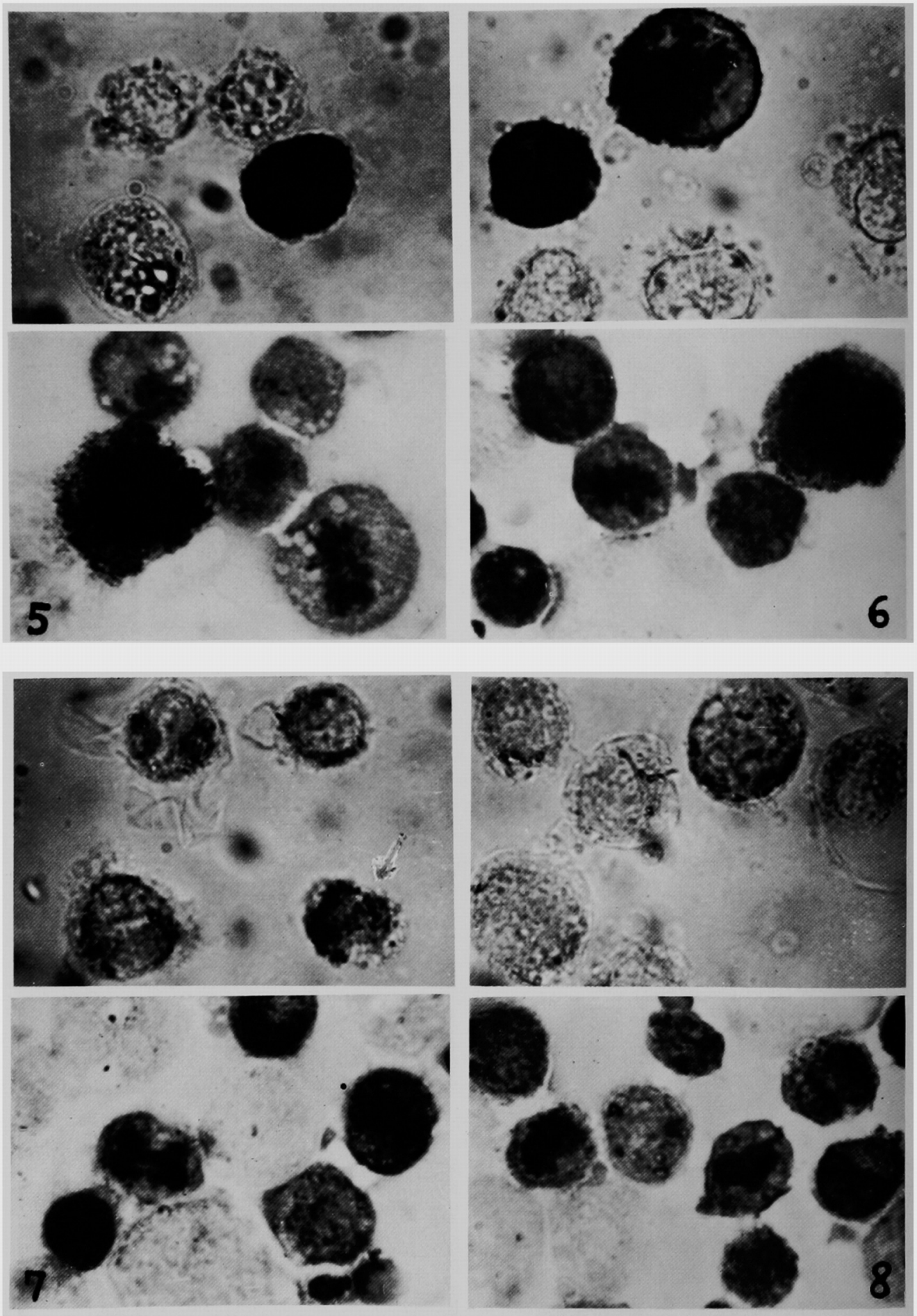
河岛論 文附国
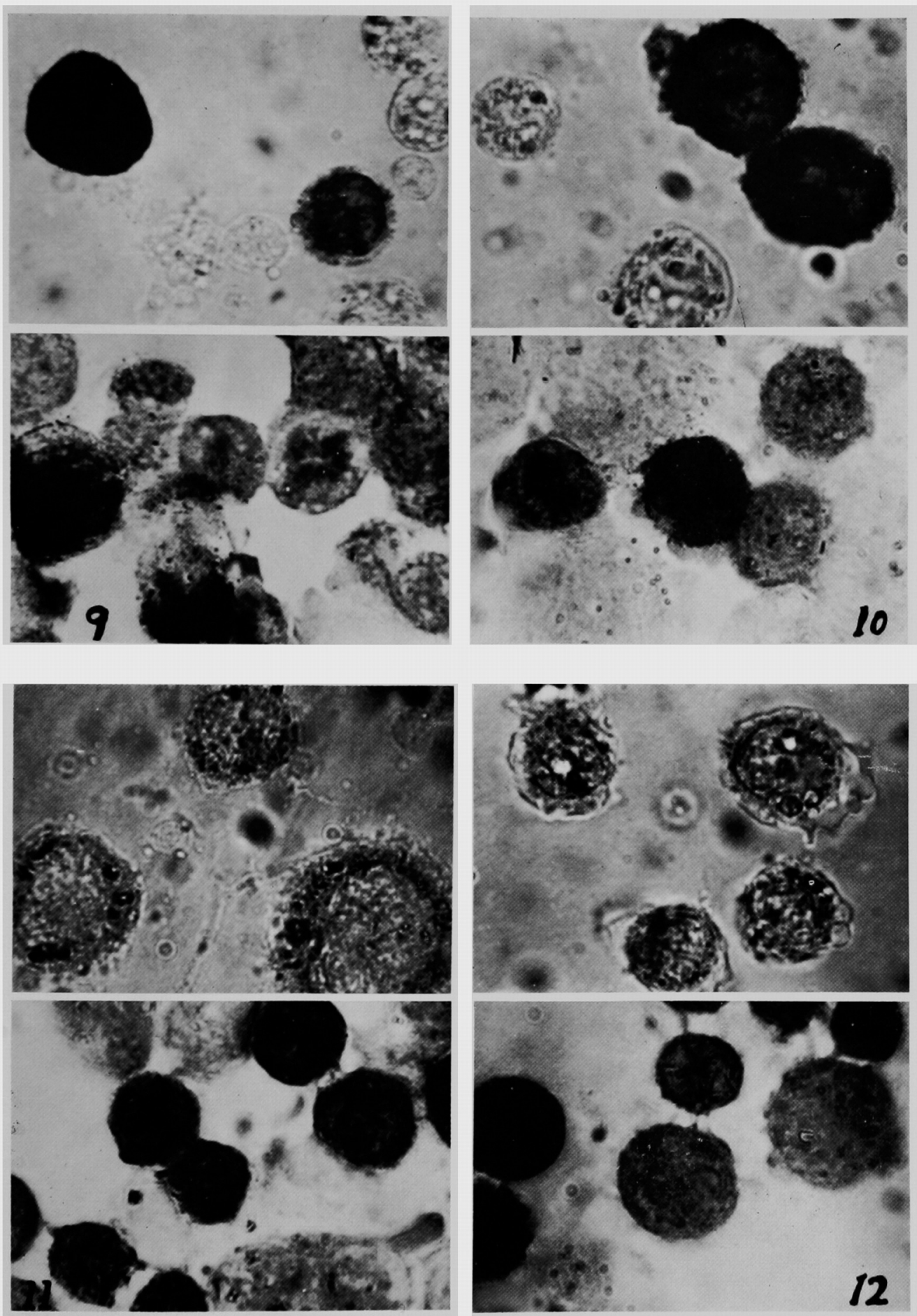
河島論文胕 匈
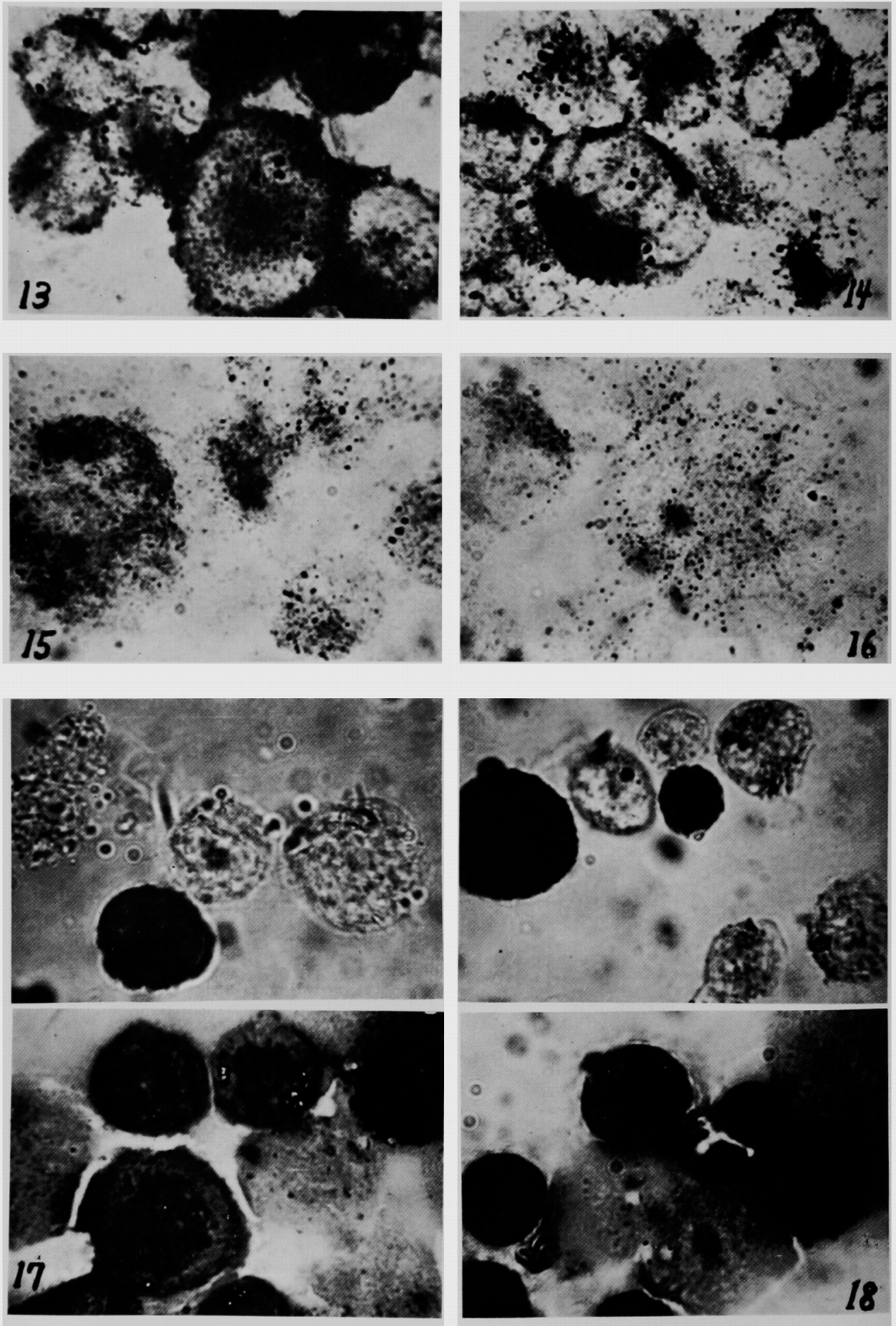
河 論 文 附 図
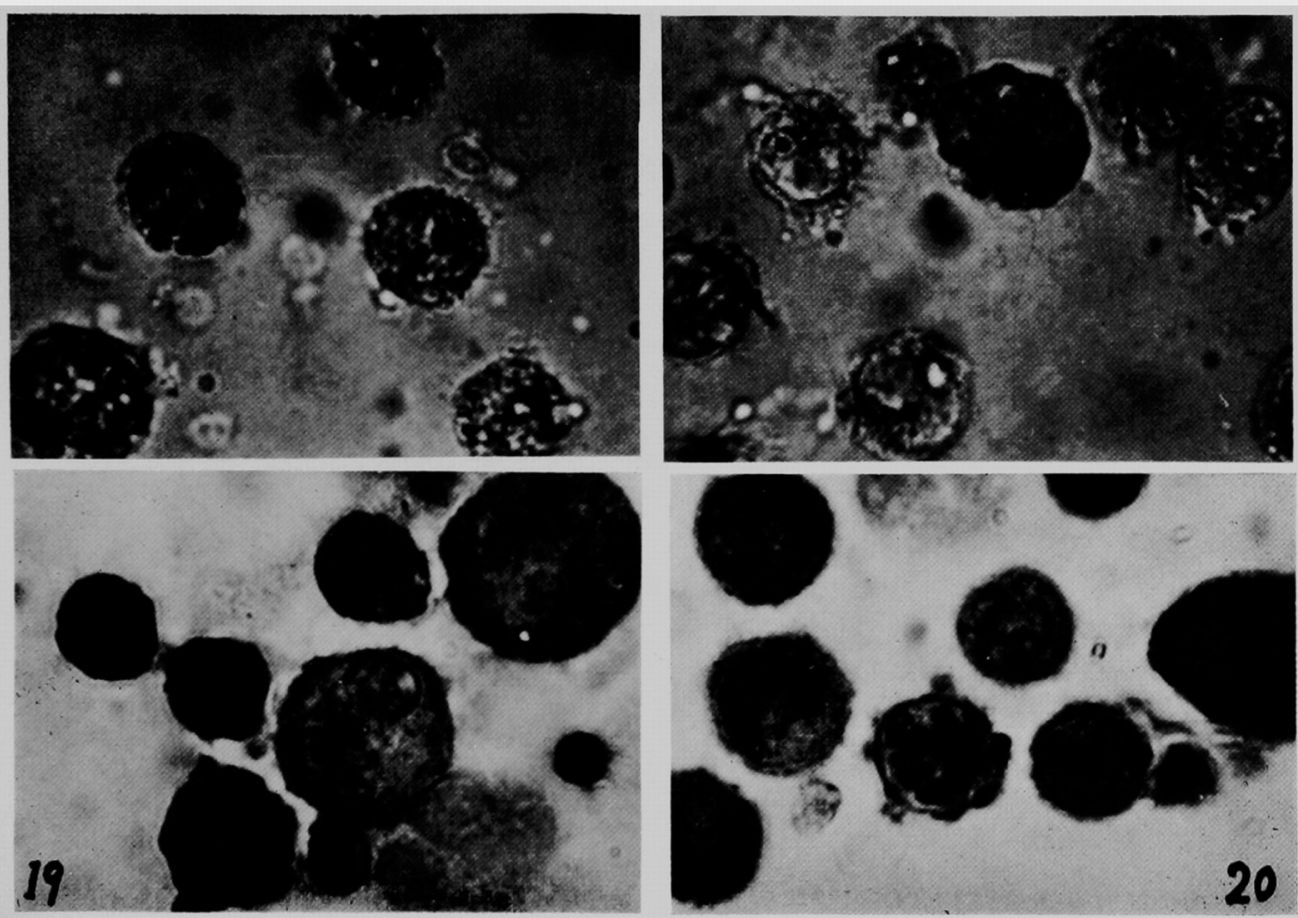